Marketring AND BRANDING
RESEARCH $\begin{gathered}\text { INDUSTRIAL } \\ \text { MANAGEMENT } \\ \text { INSTITUTE }\end{gathered}$

\title{
Recognition and ranking of customer financing methods in international trade: An approach to customers' satisfaction in the Export Development Bank of Iran
}

\author{
Fatemeh Heidari $^{1}$, Ali Akhavan ${ }^{2} *$ \\ ${ }^{1}$ MSc Student, Department of Business Management, Naraq Branch, Islamic Azad University, Markazi, Iran \\ ${ }^{2}$ Department of Business Management, Naraq Branch, Islamic Azad University, Markazi, Iran
}

Keywords:

Open Account,

Prepayment, Letter of

Credit, Documentary

Collection

Correspondence:

akhavan.rmm@gmail.com

\section{AbStRact}

One of the most important events in the present era is the rapid development of international trade and the presence of countries in different areas of international trade. This issue has posed various new challenges for countries in recent years. Management of these challenges has mostly been done with the intention to achieve two objectives of economic development and promotion to different areas of international economics and global trade. Nowadays, getting customers' satisfaction is one of the most important principles in the competition among customer-oriented organizations because customers are the main motive for commercial organizations which seek major improvements for progress. Therefore, in this kind of market-based economy, banking system which is thought as one of the main constituents of the economy of every country and bears great responsibilities is not an exception to the above-mentioned principle. The purpose of this study was recognizing and ranking of customer's financing methods in international trade with an approach to customers' satisfaction. To achieve this purpose, the research questions were tested in a descriptive method of survey type. The statistical population of this study consisted of all the staff working in all branches of the Export Development Bank of Iran. The sample of the study which was selected according to cluster random sampling method consisted of 217 staff of the Export Development Bank. The data gathering instrument for this study was a questionnaire including 16 questions with a reliability of 0.85 . According to the findings, the indexes of open account, prepayment, letter of credit, and documentary collection are considered as customer financing methods in international trade. Based on the ranking presented by the method of TOPSIS, open account and prepayment had the respective higher ranks at the traditional payment system and letter of credit and documentary collection took priority over other options in modern payment system. 
Nowadays, one of the crucial principles of global competition in customer-oriented organizations is getting customers' satisfaction. This factor is of great importance because customers are the main motive for the commercial organizations which seek major improvement and progress. Therefore, in this kind of market-based economy, banking system which is thought as one of the main constituents of the economy of every country and bears great responsibilities follows the same principle (Kazemi \& Mohajer, 2009).

One of the most important events in the present era is the rapid development of international trade and the presence of countries in different areas of international trade. This issue has caused various new challenges for countries in recent years. Management of these challenges has often been done with the objective to achieve economic development and more promotion in different areas of international economics and global trade. Since service business is considered as an important part of global trade, many researchers and economists have started investigation and research at this domain (Etemad, 2013).

Many organizations know the fact that if they want to survive in this modern world they have to move toward being customer-oriented. Organizations which fail to focus on customers' needs are more product-oriented and will be soon put aside from the existence and competition cycle. The first step for making changes in banks in order to make them more customer-oriented is to gain acceptance of each and every staff to move toward customers' satisfaction and customer-orientation.

The process of trade globalization and liberalization has caused more competition in various parts of financial market so that trade globalization has caused more capital flows to emerging economy of countries. During recent years, trade globalization in the international division has developed more because of many factors such as the policies of the General Agreement on Tariffs and Trade (GATT) and the World Trade Organization (WTO). Hence, nowadays three main factors have caused many organizations to become international and develop their activities at an international level. These factors include saturation of economic system of industrialized countries, emersion of new geographical areas for trade or new trade domains, and globalization of financial systems (Etemad, 2013).

However, considering financing and payment methods used by organizations in international trade, some methods such as open account, prepayment, letter of credit, and documentary collection can be mentioned. Nowadays, customers and consumers are more cautious about the value of goods and services. In addition, globalization has made access to all types of information easier, faster, and cheaper; however, access to information was expensive, time-consuming, and even sometimes impossible at the past and the problem is solved by globalization. At the present era, many of the prices and services are marketoriented and customers are sensitive about the prices and the services they receive; therefore, it is necessary to monitor and control the prices and services more tightly.

Considering the fact that customers seek high quality services in international markets, it is of critical importance to observe standards and quality requirements in provision and delivery of services to customers (Etemad, 2013). Another factor which is very important in international markets is the price of products and services; following this, products and services need to be offered with the lowest price and highest quality. However, observing 
customers' expectations, quality requirements, and environmental standards result in the increase of the price of products. (Samadi \& Eskandari, 2011)

In international trade, organizations try to get a privileged position compared to their rivals through getting unique and exclusive advantages. On the other hand, customers and consumers always seek suppliers that provide better products or services. Understanding this difference leads the process of choosing services and helps customers with their decision for choosing suitable services. Customers often search for clues to help them find the best suppliers. To achieve this objective, customers, in addition to internal performance, observe all external evidence related to the dominance of the principle of quality requirements in organizations. Recognition of customer financing methods in international trade with an approach to customers' satisfaction can lead to progress, economic development, and more promotion of the Export Development Bank of Iran to international economics and global markets.

Considering the above-mentioned facts, the awareness of authorities and managers of the Export Development Bank of Iran of the rules and requirements of trade and production at international level and their access to detailed, accurate, and timely information about products, markets, and rivals and their recognition of customer financing methods in international trade with an approach to customers' satisfaction can decrease the cost of wrong decisions and cause more promotion of this bank into global markets. To this end, the current study was an investigation into the recognition and ranking of customer financing methods in international trade with an approach to customers' satisfaction in the Expert Development Bank of Iran.

\section{The Literature Review}

A number of studies have been done to investigate the effective factors in international trade. Tosirkani and Farzizade (2010) tried to recognize and classify the factors effective on Iran's export of software. In this study, they attempted to classify these factors from the viewpoint of top exporting organizations using the general model of analysis of the effective factors on the export of software. In another study, Etemad (2013) considered the financing and payment methods in international trade and tried to recognize different methods for providing services to bank customers and he tried to investigate the efficient use of these methods. The results of this study demonstrated that steady development of communication and information management and harmony between different parts of banks and affiliated institutions and other organizations and institutions can improve the process of giving services to customers, and this improved process can, in turn, help the banks to realize their general strategies designed for achieving their objectives.

On the other hand, a number of researchers have aimed to study the factors which affect customers' satisfaction. N. Dehghan and K. Dehghan (2009), Agbor (2011), Mohsan, Nawaz, Sarfraz Khan, Shaukat, and Aslam (2011), Yuksel, Yuksel, and Bilim (2010), Mohammad and Alhamadani (2011), Siddiqi (2011), Lien and Kao (2008), Farquhar and Panther (2008), and Hafeez and Muhammad (2012) are just a few to mention.

N. Dehghan and K. Dehghan (2009) made an effort to recognize and prioritize the factors affecting the increase of the number of customers and influencing their decision for choosing 
a specific bank. The results of this research showed that access to banking services, type of services and its appeal to the customers, advantages of banking information, customers' security and financial trust, the quality of official and physical facilities of banks and their amenities, behavioral characteristics of the bank personnel, and the quality of bank services have direct influence on customers' satisfaction.

Agbor (2011) investigated the relationship between service quality and customers' satisfaction. The findings of her study displayed distinctive results for the relationship between service quality dimensions and service quality/customers' satisfaction. Forex and ICA had significant relationship between customers' satisfaction and service quality; however, there were no significant relationship between service quality and customers' satisfaction in Umea University. Furthermore, these findings showed that reliability, empathy, and responsiveness were significantly related to service quality, reliability, and empathy which were significantly related to customers' satisfaction. Although, responsiveness was not significantly related to customers' satisfaction, service quality was significantly related to customers' satisfaction.

Mohsan et al. (2011) studied the effect of customers' satisfaction on customers' loyalty and intentions to switch. The findings showed that customers' satisfaction had a positive effect on customers' loyalty and negative effect on customers' intentions.

Yuksel, Yuksel, and Bilim (2010) investigated the effects of customers' satisfaction and knowledge on their loyalty towards bank. The results of this study proved that costumers' positive feelings could increase their loyalty.

Mohammad and Alhamadani (2011) investigated service quality perspectives and customers' satisfaction in commercial banks working in Jordan. The results of their study indicated that service quality was the main antecedents of customers' satisfaction. They suggested that managers and decision makers in Jordanian commercial banks seek and improve the elements of service quality that determine the most important factors that contribute to customers' satisfaction.

Siddiqi (2011) conducted a study to find and apply the interrelationship between service qualities attributes, customers' satisfaction, and customers' loyalty in retail banking sector of Bangladesh. The results revealed that all service quality attributes had a positive effect on customers' satisfaction and customers' satisfaction had a positive effect on customer loyalty in the retail banking settings in Bangladesh. Empathy and tangibility demonstrated the highest and the least positive correlation with customers' satisfaction, respectively.

Lien and Kao (2008) investigated the impacts of service quality dimensions on customers' satisfaction across different types of services. The findings revealed that technical quality had highly significant effect on the satisfaction of utilitarian services. In addition, functional quality had a more important determinant role in hedonic than utilitarian services. They concluded that the relationship between service quality dimensions and satisfaction varied with the degree of differentiation of other alternatives.

Farquhar and Panther (2008) tried to find some ways for acquiring and retaining customers in UK banks. Doing an exploratory research, they found some methods for the simultaneous attraction and retention of profitable customers. 
Finally, Hafeez and Muhammad (2012) studied the impact of service quality, customers’ satisfaction, and loyalty programs on customers' loyalty. They argued that service quality, customers' satisfaction, and loyalty programs are important factors that can enhance the loyalty of customers; therefore, banks should focus more on providing loyalty programs to their loyal valued customers. Furthermore, research showed that banks should focus on improving the quality of their services for greater customers' satisfaction and customers' loyalty.

\section{Method}

Considering the type and purpose of the present study, it is regarded as an applied research because it seeks tangible and scientific results. On the other hand, it is also considered as a descriptive research because it tried to analyze and report some of the variables at the present status of affairs without manipulating them. However, considering the method, the current study was a cross-sectional survey.

The statistical population for the study consisted of all the personnel from all branches of the Export Development Bank of Iran. According to the obtained data, the total number of personnel was 500. Then, the Krejcie and Morgan's (1970) table for determining sample size was used and 217 personnel from all branches of the Export Development Bank of Iran were chosen using multistage cluster random sampling.

Two methods were used for gathering data, namely, library method and field method. The data gathering instrument used in this study was a researcher-made questionnaire consisted of 16 items based on Likert scales ranging from strongly disagree to strongly agree.

In the current study, there was an attempt to make the structure of the sentences of the questionnaire clear so that the validity of the questionnaire was verified. After initial design of the questionnaire, the researcher took advantage of the advice of university experts. In addition, since the statistical population of the research consisted of professional people related to the purposes of this study, it was hoped that the most of the population were familiar with this technique for gathering data.

In this research, the questionnaire for investigating the importance of criteria was completed by the experts. Cronbach's alpha was used to assess the reliability of the questionnaire. The alpha level was 0.85 which meant that the questionnaire had an acceptable reliability level.

\section{Results}

Four financing methods were analyzed in this study and the data related to the descriptive statistics of these financing methods are given in Table 1. 
Table 1

Descriptive Statistics of Four Financing Methods

\begin{tabular}{|c|c|c|c|c|c|}
\hline & Item & Min & Max & $\mathrm{M}$ & SD \\
\hline \multirow{4}{*}{ 芯 } & Improvement of competition in global markets & 3 & 5 & 3.7 & 0.77 \\
\hline & Creation and maintenance of successful business relationship & 3 & 5 & 4.2 & 0.77 \\
\hline & High risk of lack of payment & 3 & 5 & 3.8 & 0.73 \\
\hline & Extra costs for reducing risks using financing methods such as factoring & 3 & 5 & 3.7 & 0.68 \\
\hline \multirow{4}{*}{ 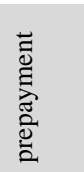 } & Payment before sending goods or services & 3 & 5 & 4.2 & 0.79 \\
\hline & Removing the risk of lack of payment & 3 & 5 & 4 & 0.72 \\
\hline & $\begin{array}{l}\text { Possibility of losing customers and their attraction by rival organizations which have } \\
\text { better payment conditions }\end{array}$ & 3 & 5 & 4 & 0.76 \\
\hline & Lack of additional revenue from financing methods & 3 & 5 & 4.1 & 0.75 \\
\hline \multirow{4}{*}{ 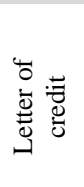 } & Payment after sending goods or services & 3 & 5 & 3.7 & 0.68 \\
\hline & Having several methods for payment, financing, and reducing risks & 3 & 5 & 3.8 & 0.71 \\
\hline & Working process is complicated and energy-consuming & 3 & 5 & 3.9 & 0.8 \\
\hline & Compared to trading costs, it is partly expensive & 3 & 5 & 3.7 & 0.73 \\
\hline \multirow{4}{*}{ 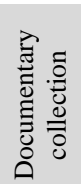 } & Getting help from the bank for the receipt of payments & 3 & 5 & 3.8 & 0.71 \\
\hline & Simplicity, rapidity, and cheapness of the process compared to letter of credit & 3 & 5 & 3.9 & 0.82 \\
\hline & The role of banks is limited and they do not guarantee payment & 3 & 5 & 3.8 & 0.68 \\
\hline & Banks do not control the truth of documents & 3 & 5 & 3.9 & 0.71 \\
\hline
\end{tabular}

Note: $n=217$

According to Table 1, the criterion of "creation and maintenance of successful business relationship" had the highest mean of 4.18 and the criterion of "extra costs for reducing risks using financing methods such as factoring" had the lowest mean of 3.69 in the variable of open account. However, in the variable of prepayment, the criterion of "payment before sending goods or services" had the highest mean of 4.16 and the criterion of "removing the risk of lack of payment" had the lowest mean of 3.95. On the other hand, the criterion of "working process is complicated and energy-consuming" produced the highest mean of 3.93 and the criterion of "compared to trading costs, it is partly expensive" made the lowest mean of 3.65 in the variable of letter of credit. Finally, in the variable of documentary collection, the criterion of "simplicity, rapidity, and cheapness of the process compared to letter of credit" had the highest mean of 3.94 and the criterion of "the role of banks is limited and they do not guarantee payment" made the lowest mean of 3.75 .

In data analysis stage, the decision analysis method of TOPSIS was used to prioritize customers' financing methods in international trade. The results of the hierarchical process of TOPSIS are presented in Table 3. At this study, seven steps were taken to prioritize financing methods. These steps consisted of the creation of decision matrix, the normalization of decision matrix, the creation of weighted non-scale decision matrix, the determination of the positive and negative ideal solutions, the calculation of the distance from positive and negative ideal solutions, the calculation of the proximity of each criterion to the positive and negative ideal solutions, and ranking of the options.

In the first step, the decision-making matrix had to be created. Therefore, a matrix was created that had the alternatives at the rows, the criteria at the columns, the weight of criteria at the last row, and the amount of importance that each respondent granted for every option according to the related criterion at the intersection of rows and columns. Table 2 illustrates a standard decision-making matrix and Table 3 shows the decision-making matrix for this 
research. It needs to be considered that the decision-making matrix (Table 3) was the mean of all experts' opinions.

Table 2

Decision-Making Matrix (N)

\begin{tabular}{ccccc}
\hline Criterion Alternative & $\mathrm{C}_{1}$ & $\mathrm{C}_{2}$ & $\ldots$ & $\mathrm{C}_{\mathrm{n}}$ \\
\hline $\mathrm{A}_{1}$ & $\mathrm{r}_{11}$ & $\mathrm{r}_{12}$ & $\ldots$ & $\mathrm{r}_{1 \mathrm{n}}$ \\
$\mathrm{A}_{2}$ & $\mathrm{r}_{21}$ & $\mathrm{r}_{22}$ & $\ldots$ & $\mathrm{r}_{2 \mathrm{n}}$ \\
$\vdots$ & $\vdots$ & $\vdots$ & & $\vdots$ \\
$\mathrm{A}_{\mathrm{m}}$ & $\mathrm{r}_{\mathrm{m} 1}$ & $\mathrm{r}_{\mathrm{m} 2}$ & $\ldots$ & $\mathrm{r}_{\mathrm{mn}}$ \\
$\mathrm{W}_{\mathrm{j}}$ & $\mathrm{W}_{1}$ & $\mathrm{~W}_{2}$ & $\ldots$ & $\mathrm{W}_{\mathrm{n}}$ \\
\hline
\end{tabular}

Note: $r_{i j}=$ the performance of alternative $i$ on criterion $j ; w_{j}=$ the weight of criterion $j$.

Table 3

Decision-Making Matrix for this Research

\begin{tabular}{ccc}
\hline & $\mathrm{C}_{1}$ & $\mathrm{C}_{2}$ \\
\cline { 2 - 3 } Criterion & Positive & Positive \\
\hline A $_{1}$ (Open Account) & 9 & 10 \\
A $_{2}$ (Prepayment) & 5 & 6 \\
A $_{3}$ (Letter of Credit) & 7 & 4 \\
$\mathrm{~A}_{4}$ (Documentary Collection) & 4 & 8 \\
Weight & 0.5 & 0.5 \\
\hline
\end{tabular}

In the second step, the decision-making matrix had to be normalized. Therefore, it was normalized or changed into a non-scale matrix $\left(\mathrm{N}_{1}\right)$ using equation 1 to make the research matrix more comparable. Equation 1 is as follows:

$$
n_{i j}=\frac{r_{i j}}{\sqrt{\sum_{i=1}^{m} r_{i j}^{2}}}
$$

The normalized research matrix is illustrated in Table 4.

Table 4

Non-Scale Matrix $\left(N_{1}\right)$

\begin{tabular}{ccc}
\hline Criterion & $\mathrm{C}_{1}$ & $\mathrm{C}_{2}$ \\
\hline $\mathrm{A}_{1}$ (Open Account) & 0.68 & 0.68 \\
$\mathrm{~A}_{2}$ (Prepayment) & 0.38 & 0.40 \\
$\mathrm{~A}_{3}$ (Letter of Credit) & 0.53 & 0.54 \\
$\mathrm{~A}_{4}$ (Documentary Collection) & 0.30 & 0.27 \\
\hline
\end{tabular}

In the third step, weighted non-scale matrix (V) was created. To get this matrix, the normalized matrix (achieved from the second step) was multiplied by square matrix $\left(w_{n \times n}\right)$ which had the weight of criteria on its main diameter and zero for other elements of the matrix.

Equation 2 is as follows:

$$
V=N_{1} \times w_{n \times n}
$$

An illustration of the weighted non-scale matrix is presented in Table 5. 
Table 5

Weighted Non-Scale Matrix

\begin{tabular}{ccc}
\hline Criterion & $\mathrm{C}_{1}$ & $\mathrm{C}_{2}$ \\
\hline $\mathrm{A}_{1}$ (Open Account) & 0.34 & 0.34 \\
$\mathrm{~A}_{2}$ (Prepayment) & 0.19 & 0.20 \\
$\mathrm{~A}_{3}$ (Letter of Credit) & 0.26 & 0.27 \\
$\mathrm{~A}_{4}$ (Documentary Collection) & 0.15 & 0.13 \\
\hline
\end{tabular}

In the forth step, positive and negative ideal solutions were determined. Therefore, the alternatives that were considered the most and less important by the respondents were recognized. In other words, regarding the positive criteria, the greatest amount of $\mathrm{V}$ was considered as the positive ideal solution and the smallest amount of $\mathrm{V}$ was considered as the negative ideal solution. However, considering the negative criteria, the positive ideal solution was the smallest amount of $\mathrm{V}$ and the negative ideal solution was the greatest amount of $\mathrm{V}$. Equation 3 and 4 illustrate this issue.

Equation 3:

$$
A^{+}=\left\{\left(\max _{i}|j| j \in J\right),\left(\operatorname{mir}_{i} V_{i j} j \in J^{\prime}\right) \mid i=1,2, \ldots m^{\prime}\right\}=\left\{V_{1}^{+}, V_{2}^{+}, \ldots . V_{n}^{+}\right\}
$$

Equation 4:

$$
A=\left\{\left(\min _{i} i_{i j} j \in J\right),\left(\max _{i} \mid j \in J^{\prime}\right) \mid i=12, \ldots m_{n}\right\}=\left\{V_{1}, V_{2}, \ldots V_{n}\right\}
$$

$\mathrm{J}$ was the positive criteria and the negative criteria respectively in equations 3 and 4 . Table 6 shows positive and negative ideal solutions.

Table 5

Positive and Negative Ideal Solutions of Each Criterion

\begin{tabular}{ccc}
\hline Criterion & Positive Ideal Solution & Negative Ideal Solution \\
\hline $\mathrm{C}_{1}$ (traditional methods of payment) & 0.34 & 0.15 \\
$\mathrm{C}_{2}$ (modern methods of payment) & 0.34 & 0.13 \\
\hline
\end{tabular}

The fifth step consisted of the calculation of the distance from positive and negative ideal solutions. Therefore, the distance of each alternative from positive and negative ideal solutions was determined using equations 5 and 6 .

Equation 5:

$$
d_{i}^{+}=\sqrt{\sum_{j=1}^{n}\left(V_{i j}-V_{j}^{+}\right)^{2}} ; i=1,2, \ldots, m
$$

Equation 6:

$$
d_{i}^{-}=\sqrt{\sum_{j=1}^{n}\left(V_{i j}-V_{j}^{-}\right)^{2}} ; i=1,2, \ldots, m
$$

The results of the calculation of distances are presented in Table 6 . 
Table 6

Ranking of Alternatives

\begin{tabular}{ccccc}
\hline Number & Alternative & $\begin{array}{c}\text { Distance from Positive Ideal } \\
\text { Solution }\end{array}$ & $\begin{array}{c}\text { Distance from Negative Ideal } \\
\text { Solution }\end{array}$ & CL \\
\hline 1 & $\mathrm{~A}_{1}$ & 0.00 & 0.28 & 1 \\
2 & $\mathrm{~A}_{2}$ & 0.20 & 0.07 & 0.27 \\
3 & $\mathrm{~A}_{3}$ & 0.10 & 0.17 & 0.63 \\
4 & $\mathrm{~A}_{4}$ & 0.28 & 0.00 & 0.00 \\
\hline
\end{tabular}

In the sixth step the proximity of each criterion to positive and negative ideal solutions (CL) were determined using equation 7.

$$
C L_{i}=\frac{d_{i}^{-}}{d_{i}^{-}+d_{i}^{+}}
$$

Table 6 illustrated the ranking of alternatives and the amounts of CL related to each alternative. The last step consisted of prioritizing alternatives. In this stage, the alternatives were prioritized according to the amounts of CL, so that any alternative with a higher CL took a better rank.

\section{Conclusion}

The results of ranking alternatives using the TOPSIS technique demonstrated that the alternative of open account had a higher rank compared to other alternatives in the traditional methods of payment. However, after open account, the alternative of prepayment was at the second rank. On the other hand, the alternative of letter of credit was at the first rank and documentary collection was at the second rank in the modern methods of payment. The findings of this study should be viewed within the context of its limitations. The findings were based on a sample of 217 personnel who were approached for the study from all branches of the Export Development Bank of Iran. Future studies should extend this work and since the current study were assessed through questionnaire only, in subsequent studies, researchers could make use of other kinds of assessment tools such as observation, interviewing, or a combination of different assessment devices. In the present study, gender was not considered; therefore, the research could be carried out with sufficient number of participants from each sex. Following this, since the study was conducted only in branches of Export Development Bank of Iran, further research is needed in other banks or institutions to compare the results.

\section{References}

Agbor, J. M. (2011). The relationship between customer satisfaction and service quality: A study of three service sectors in Ugenda. Marketing Review, 2(1), 1-85.

Dehghan, N., \& Dehghan, K. (2009). Recognition and prioritizing the factors affecting customer satisfaction in banks. Paper presented at the First International Conference of Marketing of Bank Services, Tehran, Iran.

Etemad, A. (2013). Financing and payment methods in international trade. Paper presented at $21^{\text {st }}$ Conference on Banking, Tehran, Iran.

Farquhar, J. D., \& Panther, T. (2008). Acquiring and retaining customers in UK banks: An exploratory study. Journal of Retailing \& Customer Services, 15(1), 9-21.

Hafeez, S., \& Muhammad, B. (2012). The impact of service quality, customer satisfaction, and loyalty programs on customer's loyalty: Evidence from banking sector of Pakistan. International Journal of Business \& Social Science (Special Issue), 3(16), 200-209. 
Kazemi, M., \& Mohajer, S. (2009). Ranking of the factors affecting customer satisfaction and service quality of bank branches of modern economics. Journal of Industrial Management Faculty of Humanities, 4(10), 91-103.

Krejcie, R.V., \& Morgan, D.W., (1970). Determining Sample Size for Research Activities. Educational and Psychological Measurement, 30, 607-610.

Mohammad, A. A. S., \& Alhamadani, S. Y. M. (2011). Service quality perspectives and customer satisfaction in commercial banks working in Jordan. Middle Eastern Finance \& Economics, 14, 60-72.

Mohsan, F., Nawaz, M. M., Sarfraz Khan, M., Shaukat, Z., \& Aslam, N. (2011). Impact of customer satisfaction on customer loyalty and intentions to Switch: Evidence from banking sector of Pakistan. International Journal of Business \& Social Sciences, 2(10), 263-270.

Lien, N. H., \& Kao, S. L. (2008). The effects of service quality dimensions on customer satisfaction across different service types: Alternative differentiation as a moderator. Advances in Consumer Research, 35, 522-526.

Samadi, A., \& Eskandari, S. (2011). The effects of service quality on customer satisfaction on Melli bank in Toyserkan, Hamedan Iran (based on servqual model). Management Quarterly, 8(20), 21-30.

Siddiqi, K. O. (2011). Interrelations between service quality attributes, customer satisfaction, and customer loyalty in the retail banking sector in Bangladesh. International Journal of Business \& Management, 6(3), 12-36.

Tosirkani, M., \& Farzizade, Z. (2010). Recognition and ranking of the factors effective on Iran's export of software. Planning \& Budgeting, 111, 141-158.

Yuksel, A., Yuksel, F., \& Bilim, Y. (2010). Destination attachment: Effects on customer satisfaction and cognitive, affective, and conative loyalty. Tourisim Management, 31(2), 274-284. 